\title{
Efficacy and Safety of Weekly Low Dose Paclitaxel and Cisplatin as First Line Therapy in Advanced NSCLC of Elderly Patients
}

Purpose: Anti-cancer chemotherapeutic agents act by inhibiting tumor cell proliferation through cytotoxic action, therefore the generally tolerated maximum dose is administered to patients. However, this often results in the production of undesirable toxicities, such as bone marrow suppression, and a long interruption of treatment is necessary for recovery to occur before additional cycles of treatment are administered. Paclitaxel and cisplatin are well known effective chemotherapeutic agents used for the treatment of Non-Small Cell Lung Cancer (NCSLC), however, they have substantial toxicities. To evaluate efficacy and safety of a therapy consisting of a weekly low dose of paclitaxel and therapy in elderly patients with advanced NSCLC. Materials and Methods: Thirteen treatment-naive, elderly patients over 65 years old who were diagnosed with stage IV NSCLC at Konyang University from April 2005 to October 2006 were enrolled in the present study. Paclitaxel at a dose of 55 $\mathrm{mg} / \mathrm{m}^{2}$ in combination with cisplatin at a dose of $20 \mathrm{mg} / \mathrm{m}^{2}$ was administered intravenously on day 1,8 , and 15 with 1 week of interruption for a total of six cycles of chemotherapy. Results: The mean age of the ten patients included in this study was 69.5 years. Following treatment, $50 \%$ of the patients exhibited a partial response to treatment, whereas the disease remained stable in $40 \%$ of the patients, and progressed in $10 \%$ of the patients. The median survival time (Kaplan-Meier method) was 15 months (4 24 months), and the 6-month, 1-year, and 2-year survival rates were $80 \%, 50 \%$, and $10 \%$, respectively. The median progression survival time was 8 months $(2 \sim 14$ months) and the 6- and 12-month progression free survival rates were $60 \%$ and $10 \%$, respectively. Grade 3 neutropenia occurred in only 1 case (10\%). Conclusion: The results of this study indicated that chemotherapy consisting of a weekly low dose of paclitaxel and cisplatin could be more effective and have lesser toxicity when administered to elderly patients with advanced NSCLC. In addition, this treatment regimen showed a promising response rate. (J Lung Cancer 2007;6(2):85-90)

Key Words: Paclitaxel, Weekly, Cisplatin, Elderly, Non-small cell lung cancer

\author{
Jung Ho Lee, M.D. \\ Mi Hye Kwon, M.D. \\ Ji Hyun Jeoung, M.D. \\ Go Eun Lee, M.D. \\ Eu Gene Choi, M.D. \\ Moon Jun Na, M.D. \\ Hyun Min Cho, M.D. ${ }^{1}$ \\ Young Jin Kim, M.D. ${ }^{1}$ \\ Weon Kuu Chung, M.D. ${ }^{2}$ \\ Young Jun Cho, M.D. ${ }^{3}$ and \\ Ji Woong Son, M.D.
}

Departments of Internal Medicine, ${ }^{1}$ Chest Surgery, ${ }^{2}$ Therapeutic Radiology and Oncology, ${ }^{3}$ Radiology, College of Medicine, Konyang University, Daejeon, Korea

Received: October 16, 2007

Accepted: November 9, 2007

\author{
Address for correspondence \\ Ji Woong Son, M.D. \\ Department of Internal Medicine, Col- \\ lege of Medicine, Konyang University, \\ 685, Gasuwon-dong, Seo-gu, Daejeon \\ 302-718, Korea \\ Tel: $82-42-600-8817$ \\ Fax: $82-42-600-9090$ \\ E-mail: sk1609@hanmail.net
}

\section{서 론}

2005년 우리나라 사망자의 사망원인 중 암은 10 만명당 134.5 명으로 현재 22 년째 사망원인의 1 위를 지키고 있으며, 폐암은 암에 의한 사망률 원인의 1 위이며 전체 암발생률의 2위를 차지하고 있는 실정이다(1). 또한 2002년 한국 중앙암 등록사업 연례보고서에 의하면 65 세 이상의 폐암환자가
$56 \%$ 를 차지하고 있으며 폐암환자의 비율은 점차적으로 늘 어나고 있다(2). Kim 등이 시행한 조사연구의 통계결과를 살펴보면 비소세포성 폐암은 전체 폐암에서 $82.3 \%$ 를 차지 하고 있었고, 단지 $27.1 \%$ 만 수술이 가능한 상태였다(3).

폐암이 진단될 당시 초기일 경우에는 광범위한 절제를 통한 완치를 치료의 목적으로 하나 진행성의 경우에는 화 학요법으로의 치료를 원칙으로 하고 있다(4). Paclitaxel과 
cisplatin은 비소세포성 폐암에서 유용한 항암화학요법 제로, paclitaxel은 진행성 비소세포성 폐암에서도 단독요법으로 $11 \sim 38 \%$ 의 효과가 있음이 보고되고 있으며(5) cisplatin은 여러 연구에서 vinorelbin, gemcitabine, paclitaxel과의 조합이 기존 구세대의 복합화학요법보다 월등한 결과를 보이고 있 다(6 8). 항암제들은 세포독성작용을 통해 암세포를 파괴 시키고 증식을 억제하기 때문에 통상적으로 최대사용 용량 을 사용해야 한다는 이론을 근거로 이전에 보고된 paclitaxel 과 cisplatin의 병합요법은 전통적으로 paclitaxel 135 250 $\mathrm{mg} / \mathrm{m}^{2}(7,9,10)$ 와 cisplatin $60 \sim 120 \mathrm{mg} / \mathrm{m}^{2}$ 의 용량을 매 3주마 다 사용하였다(11). 항암화학요법에 사용되는 항암제들의 최대사용 용량은 예기치 못한 부작용이 발생할 수 있으며 정상수용세포가 회복될 때까지 비치료 기간을 가져야 하는 과정이 필요하다. 이러한 이유로 최근 들어 저용량의 항암 제를 이용해 매주 일정에 따라 시행하는 paclitaxel과 cisplatin의 복합항암화학용법이 비슷한 효과와 함께 안전하게 사용할 수 있는 것으로 발표되었다(12).

현재 전 세계적으로 인구의 고령화가 진행되고 있으며 폐암의 노령인구 역시 늘어나고 있는 실정이고, 항암화학 요법 역시 고령의 환자에서 유의한 항암효과와 함께 항암 제의 부작용을 최소한 억제하는 것이 필요하므로 이전에 있던 원칙만을 그대로 적용하기는 힘들며 다른 접근이 필 요하다. 이전까지는 동반질환과 다른 장기의 기능장애, 환 자 및 보호자의 치료에 대한 수동성 등으로 폐암환자의 발 생연령이 증가함에도 여러 임상연구가 시행되지 못했으며 최근 들어서야 고령인구에서의 진행성 비소세포 폐암환자 의 vinoralbine, gemcitabine 등의 단독요법의 연구가 보고되 고 있다 $(13,14)$. 본 연구에서는 65 세 이상의 고령인구에서 4 기의 비소세포성 폐암환자에게 있어 저용량의 매주 항암 치료의 부작용의 정도와 효용성 등을 확인해 보았다.

\section{대상 및 방법}

\section{1) 대상환자}

2005년 4월부터 2006년 10월까지 비소세포성 폐암을 진 단받고 복합항암화학요법을 시행 받은 환자를 대상으로 하 였다. 대상 환자는 65 세 이상의 고령 환자로 기관지 내시경 및 흉부전산화단층 촬영을 이용한 조직검사를 통해 병리 조직학적으로 확진이 되었으며, 과거에는 어떠한 화학요법 을 받지 않았고 계측이 가능한 병변을 가지고 있고, 활동의 정도가 Eastern Cooperative Oncology Group (ECOG) 기준 0 2이며, 적절한 골수, 간, 신기능을 가지고 있고(호중구 $1,500 / \mathrm{mm}^{3}$ 이상, 혈소판 $100,000 / \mathrm{mm}^{3}$ 이상, 혈청 빌리루빈
은 정상 상한치의 1.5 배 이하, alanine anminotranferase, aspartate aminotransferase는 정상 상한치의 3 배 이하, 혈청 크 레아티닌수치는 $1.5 \mathrm{mg} / \mathrm{dl}$ 이하) 치료에 영향을 줄 수 있는 다른 심각한 질환을 않고 있지 않는 경우로 하였다. 조절되 지 않는 심질환이 있거나, 조절되지 않는 활동성 감염이 있 는 환자, 2 등급 이상의 말초신경장애가 있는 환자, 뇌전이 이외의 중추신경계 질환의 병력이 있는 환자, 기타 연구자 가 본 연구에 포함시키기 어렵다고 판단한 환자는 제외하 였다. 치료 전 모든 환자에게서 병력청취 및 신체검사를 시 행하였고 혈액 검사와 소변검사, 심전도와 폐기능 검사를 확인하였다.

\section{2) 치료방법}

치료를 위해 환자가 내원시 매 방문마다 추가적인 병력 청취 및 신체검사, complete blood count (CBC), 혈청 크레아 티닌 등의 혈청학적인 검사를 시행하였다.

매주 시행하는 약물요법은 1시간 동안 paclitaxel을 55 $\mathrm{mg} / \mathrm{m}^{2}$ 의 용량으로 정주하였으며 paclitaxel 정주가 끝난 후 Cisplatin은 $20 \mathrm{mg} / \mathrm{m}^{2}$ 의 용량으로 30 분 동안에 정주하였으 며 제 $1,8,15$ 일째 약물요법을 시행하였으며, 28 일 간격으로 원칙적으로 6주기(cycle)를 투여하였다. Paclitaxel을 투여하 기 전에 anaphylaxis를 예방하기 위하여 chlorpheniramin, ranitidine, dexamethasone으로 처치를 시행하였다.

\section{3) 치료 효과 및 독성 평가}

치료 효과에 대한 평가를 위해 매 2주기마다 흉부전산화 단층촬영과 필요시 전신골주사를 시행하였고, 임상증상의 악화가 있는 경우에도 시행하였다.

치료 효과의 판정은 RECIST를 적용시키되 2주기(8주)를 검사적용시기로 잡았으며, 따라서 임상적으로 계측이 가능 한 병변이 완전 소실되고 8주 이상 지속되는 경우 완전 관 해, 측정 가능한 병변의 최장 직경 합이 $30 \%$ 이상 감소하면 서 8주 이상 지속되고 새로운 병변이 생기지 않으면서 다른 병변의 진행이 없는 경우 부분 관해, 새로운 병변의 발생 없이 병변의 최장 직경 합이 $30 \%$ 이하로 줄거나 $25 \%$ 이하 로 증가하면 불변(Stable disease), 한 개 이상 병변에서 $25 \%$ 이상 증가하거나 새로운 병변이 발견된 경우를 진행으로 하였다.

매 항암치료 전에 시행한 검사상 골수억제 소견이 보일 경우(호중구수 $\leq 1,500 / \mathrm{mm}^{3}$ ), 항암치료는 회복이 될 때까지 연기하였고 치료 후의 부작용 및 독성 평가는 $\mathrm{NCI}$ 독성평가 기준(common toxicity criteria) v2.0에 따라 등급을 정하였다. 


\section{4) 통계학적 분석}

생존기간은 치료 시작 일부터 사망일까지 또는 마지막 추적관찰 일까지로 하였고, 무진행 생존기간은 치료 개시 일부터 질병의 진행이 관찰된 날이나 사망한 날까지로 하 였다. 부분관해 이상이 관찰되었던 환자에서 진행까지의 기간은 관해가 관찰된 날로부터 진행이 증명된 날까지로 하였다. 생존기간, 무진행 생존기간 중앙치는 Kaplan-Meier 법으로 산출하였다.

\section{결 과}

\section{1) 대상환자의 특성}

2005년 4월부터 2006년 10월까지 본원에 비소세포성 폐암 을 진단받고 그 중 65 세 이상이면서 전신골스캔, 뇌자기공 명영상법, PET/CT 시행결과 IV병기를 보이며, 복합항암화 학요법을 시행하는 적응증을 보인 환자는 총 36명이 등록 되었다. 36명 중 5명은 gemcitabine-cisplatin을 복합항암요법

Table 1. Patients Characteristics

\begin{tabular}{lcc}
\hline \multicolumn{1}{c}{ Characteristics } & Number of patients & $\%$ \\
\hline Entered & 10 & \\
Median age (years)(range) & $69.5(65 \sim 74)$ & \\
Sex & & \\
$\quad$ Male & 9 & 90 \\
$\quad$ Female & 1 & 10 \\
Performance status & & \\
0 & 1 & 10 \\
1 & 5 & 50 \\
2 & 4 & 40 \\
Histology & & \\
Squamous cell carcinoma & 5 & 50 \\
$\quad$ Adenocarcinoma & 5 & 50 \\
Metastatic site & & \\
$\quad$ Bone & 5 & \\
Lung & 3 & \\
Adrenal & 3 & \\
Etc & 3 & \\
\hline
\end{tabular}

으로 사용하였으며 21명은 항암치료를 원치 않거나 연고지 등의 관계로 전원, 또는 80세 이상의 고령이나, $\mathrm{ECOG}$ 가 되 지 않거나, 치료의 대상이 되지 못하는 질환을 가지고 있는 환자로 제외하였다. 나머지 총 10 명을 대상으로 하였으며 대상 환자의 평균 연령 값은 69.6세(범위 65 74세)였으며 70 세 이상이 5 명이었다. 남녀 비는 $9: 1$ 로 남자환자가 대부 분이었고, 환자의 활동도는 $\mathrm{ECOG}$ 를 기준으로 PS 0 이 1명, $\mathrm{PS} 1$ 이 5명, PS 2가 4명이었다. 병리학적인 분류로는 편평 상피암이 5명(50\%), 선암이 5명(50\%)이었다(Table 1).

\section{2) 치료반응}

10 명의 환자는 최소한 2 주기 이상의 용량의 변화 없이 항 암화학치료를 받았다. 한명의 환자에서는 진단 후 2 주기의 항암화학요법을 시행 후 진행을 보여 다른 항암제로 바꾸 어 항암화학요법을 시행하였다.

2달이 지난 후에 2주기 항암화학요법을 시행한 후 측정 한 반응률은 완전반응을 보인 환자는 없었으며 $(0 \%)$, 부분 반응 5 명 $(50 \%)$, 불변 4 명 $(40 \%)$, 진행 1 명 $(10 \%)$ 의 치료 반응 률을 보였으며(Table 2) 중앙생존기간은 15 개월이었고 , 6 개 월 및 1년, 2년 생존율은 각각 $80 \%, 50 \%, 10 \%$ 였다(Fig. 1). 중앙 무진행 생존기간은 8 개월, 6,12 개월 무진행 생존율은 $60 \%, 10 \%$ 였다(Fig. 2).

\section{3) 치료의 부작용}

혈액학적 부작용과 비혈액학적 부작용은 10명에서 165 회 (54주기)에서 평가하였다. 항암화학요법의 3 도 이상의 치료 독성은 표에 정리하였다(Table 3). 호중구 감소증에 의해 항 암화학요법을 연기하였던 적은 $10 \%$ ( 1 case)를 보였다. 빈 혈은 모두 1, 2도로 경미하였으며 혈소판 감소증 역시 마찬 가지였다. 비혈액학적 부작용으로는 식욕감퇴, 오심, 전신 쇄약 등의 증상이 보였으나 보존적 치료를 시행 후 대부분 이 회복되었으며 항암화학요법을 시행하지 못할 정도의 부 작용 정도는 관찰되지 않았다. 한 환자에서는 치료 후 정맥 염이 관찰되었다.

Table 2. Comparison with the Other Studies in the Literature

\begin{tabular}{llcccc}
\hline Author & \multicolumn{1}{c}{ Treatment Schedule } & No. of patients & Response rate & Time to progression & Median survival \\
\hline Kim & $\begin{array}{l}\text { Paclitaxel } 175 \mathrm{mg} / \mathrm{m}^{2} \\
\text { Cisplatin } 75 \mathrm{mg} / \mathrm{m}^{2}\end{array}$ & 42 & $46.3 \%$ & 5.9 (mon) & 10.5 (mon) \\
Kim & $\begin{array}{l}\text { Weekly paclitaxel } 40 \mathrm{mg} / \mathrm{m}^{2} \\
\text { Cisplatin } 20 \mathrm{mg} / \mathrm{m}^{2}\end{array}$ & 22 & $40.9 \%$ & 4 (mon) & 10.5 (mon) \\
Author & $\begin{array}{l}\text { Weekly paclitaxel } 55 \mathrm{mg} / \mathrm{m}^{2} \\
\text { Cisplatin } 20 \mathrm{mg} / \mathrm{m}^{2}\end{array}$ & 10 & $50 \%$ & 8 (mon) & 15 (mon) \\
\hline
\end{tabular}




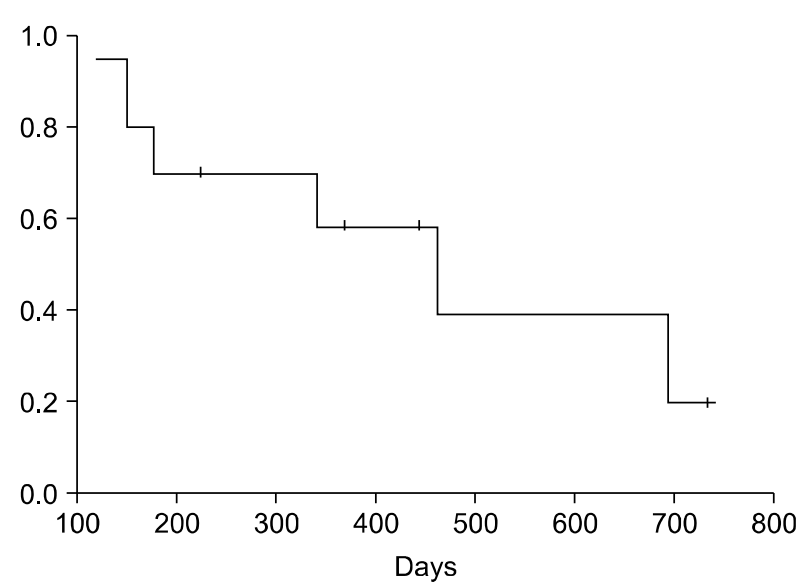

Fig. 1. Overall survival in weekly low dose paclitaxel and cisplatin for stage IV non-small cell lung cancer in elderly patients.

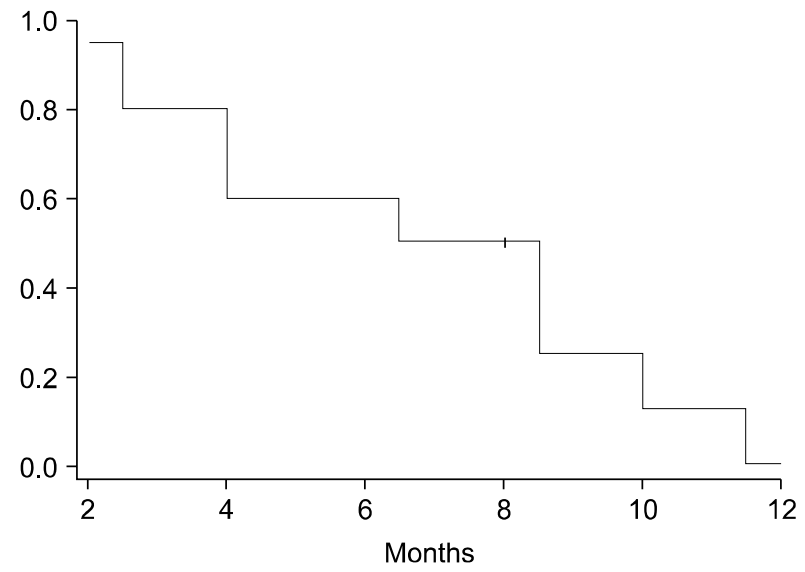

Fig. 2. Progression-free survival in weekly low dose paclitaxel and cisplatin for stage IV non-small cell lung cancer in elderly patients.

Table 3. Comparison of Toxicity (Grade III or IV)

\begin{tabular}{lccccccc}
\hline Toxicity & Cycle & Leukopenia & Anemia & Thrombocytopenia & Nausea & Neuropathy & Myalgia \\
\hline Kim & 180 & 1 & $7(3.9 \%)$ & $1(0.6 \%)$ & $6(3.3 \%)$ & $2(1.1 \%)$ & $3(1.7 \%)$ \\
Kim & 339 & 3 & 0 & 0 & 0 & 0 & 0 \\
Author & 192 & 0 & 0 & 0 & 0 & 0 & 0 \\
\hline
\end{tabular}

\section{고안 및 결론}

최근 들어 진행성 비소세포폐암 치료는 platinum을 같이 하는 복합화학요법이 많이 사용되고 있으며 그 효과도 유 용한 것으로 보고되고 있다(15). 하지만 인구의 고령화로 인한 암발생 연령은 점점 높아지고 있는 상태이며, 이것은 폐암의 경우도 마찬가지이다. 따라서 고령의 환자에게 있 어서 다른 동반질환이 많으며 여러 장기들의 기능의 장애 로 화학요법의 독성이 증가하여 복합화학요법을 시행하는 데 어려움이 따르는 실정이다. 하지만 최근 많은 연구에서 는 이러한 고령 환자에게도 최소한의 합병증 및 독성을 예 측할 수 있는 항암제제 및 치료방법이 고안, 개발되고 있다. Paclitaxel은 용량-반응 상관관계를 통해 항암제제 사용에 대한 적절한 안정용량을 제시하고 있는 여러 연구에서 135 $\sim 250 \mathrm{mg} / \mathrm{m}^{2}$ 의 용량으로 매 3주마다 사용되어 우수한 효과 를 보였다 $(7,9,10)$. Bonomi 등의 연구와 Arbuck, Gianni 등의 연구에서는 paclitaxel의 어느 정도의 고용량의 사용이 혈청 내 농도를 더 높게 형성함에도 불구하고 임상적으로 135 $\mathrm{mg} / \mathrm{m}^{2}$ 이상의 paclitaxel의 고용량은 비소세포성 폐암에서 이득이 없었다는 보고를 하였다 $(7,9,16)$. Rowinsky 등의 연 구에서는, 난소암에서 $110 \mathrm{mg} / \mathrm{m}^{2}$ 에서 $300 \mathrm{mg} / \mathrm{m}^{2}$ 용량범위 에서의 paclitaxel를 이용한 항암화학요법은 전반적인 생존
율과 paclitaxel의 용량과의 어떤 유의한 관계도 보이지 않았 다(17). 고용량의 여러 연구와는 다르게 Yeung 등은 단지 $0.005 \sim 0.05 \mu \mathrm{mol} / \mathrm{L}$ 의 낮은 용량의 paclitaxel에서도 암세포 의 유사분열동안, 방추체를 고정시켜 유사분열을 억제되었 으며 paclitaxel의 낮은 용량에서도 암세포의 자살유도작용 (apoptosis)을 일으킨다고 보고하였다(18). Gergiadis 등은 비 소세포성 폐암에서 4 일 동안 $100 \sim 180 \mathrm{mg} / \mathrm{m}^{2}$ 의 paclitaxel 용량을 지속적으로 정주한 경우, 혈청 내 농도가 0.034 $0.097 \mu \mathrm{mol} / \mathrm{L}$ 정도의 수치가 유지된 것을 보고하였고(19), $\operatorname{Kim}$ 등의 연구에서는 단지 매주 $40 \mathrm{mg} / \mathrm{m}^{2}$ 의 paclitaxel의 1 시간 정주를 통해 재발한 유방암 환자에게서 평균최고 혈 청농도 $1.94 \mu \mathrm{mol} / \mathrm{L}$ 를 보였다(20). Aisner 등은 $45 \mathrm{mg} / \mathrm{m}^{2}$ 의 저 용량의 paclitaxel을 매주 3시간 정주한 후 $0.50 \sim 0.60 \mu \mathrm{mol} /$ $\mathrm{L}$ 의 혈청농도를 보였으며 24시간까지 유효한 농도를 보여 주었다(21). 그러므로, 현재 본 연구에서 사용한 $55 \mathrm{mg} / \mathrm{m}^{2}$ 는 비소세포성 폐암환자에게 있어서 항암작용을 일으키는데 유효한 농도의 용량이라고 예측할 수 있다. 본 연구에서는 Platinum계열의 Cisplatin을 복합항암제제로 이용하였으며 paclitaxel과 cisplatin 두 항암제제들은 비소세포폐암에 대한 반응률이 높고, 부작용도 낮은 것으로 알려져 있다(22).

다른 연구와 비교해 보면, 이전 고용량의 paclitaxel에 대 한 $\operatorname{Kim}$ 등의 연구에서는 3주마다 paclitaxel $175 \mathrm{mg} / \mathrm{m}^{2}$ 와 cisplatin $75 \mathrm{mg} / \mathrm{m}^{2}$ 를 3 주 간격으로 사용한 42 명의 III기와 IV 
기의 환자에서 전체 관해율은 $46.3 \%$, 중앙생존기간은 10.5 개월, 중앙 무진행 생존기간은 5.9개월이었으며(23) 본 연구 와 마찬가지로 저용량의 매주 paclitaxel $40 \mathrm{mg} / \mathrm{m}^{2}$ 와 cisplatin $20 \mathrm{mg} / \mathrm{m}^{2}$ 를 사용한 III기와 IV기의 환자에서 전체 관해율은 $40.9 \%$, 중앙생존기간은 10.5 개월, 중앙 무진행 생존기간은 4개월이었다(12). 이번 연구의 결과를 비교해 보았을 때 중 앙생존기간, 중앙무진행 생존기간, 전체 관해율이 세 연구 중 가장 높았다. Pclitaxel은 치료용량의 강도(intensity and concentration)와 치료반응이 상관관계가 있는 것으로 알려 져 있고 최근 보고에서는 종양의 재성장과 신생혈관형성이 발생할 수 있는 비 치료기간의 사이를 좁힘으로 투약밀집 성(dose-dense) 역시 치료반응과 밀접한 관련성이 있음을 밝 히고 있다(24). 3주 고용량의 연구에 비해 최근 연구에서는 paclitaxel은 같은 용량 대비 매주 저용량의 치료가 투약강도 (dose-intensity)나 투약밀집성(dose-dense)이 우수한 것으로 보고되고 있으며(25) 이전 $\mathrm{Kim}$ 등의 매주 복합항암화학요 법이 paclitaxel을 $40 \mathrm{mg} / \mathrm{m}^{2}$ 를 사용한데 반해 본 연구에서는 $55 \mathrm{mg} / \mathrm{m}^{2}$ 의 상대적인 고용량을 쓴 것이 투약 강도면에서 우월한 결과를 가져온 것으로 생각된다. 치료를 시행 중 생 존에 영향을 미칠 정도의 부작용이 없었던 것도 생존률 향 상에 영향이 있을 것으로 생각된다.

항암복합화학요법을 연기해야 하거나 치료 자체를 중단 해야 되는 $\mathrm{NCI}$ 독성평가기준의 3 도 또는 4 도의 부작용을 비교해 보았을 때, 본 연구의 환자가 다른 연구에 비해 고령 임에도 불과하고 혈액학적 또는 비혈액학적인 3 도 이상의 부작용은 관찰되지 않았다. 다만, 한 환자에서 호중구수가 950 개로 3 도의 부작용을 보여 항암화학요법을 연기하였다. 세 연구를 비교해 보았을 때 3도 또는 4도의 부작용은 고용 량 paclitaxel과 cisplatin의 항암요법에서 더 자주 발생되었 다. 또한 같은 저용량의 paclitaxel과 cisplatin의 치료 연구에 서도 백혈구 감소증이 본 연구에서보다 많은 경우에서 발 생하였고, 이것은 paclitaxel의 용량이 $55 \mathrm{mg} / \mathrm{m}^{2}$ 로 비교연구 보다 많은 용량을 사용했음에도 불구하고 1주간의 비 치료 기간을 가졌던 것이 비 치료기간을 가지지 않고 지속적인 복합항암화학요법을 시행하였던 기존연구보다 골수기능회 복을 가질 수 있는 기간을 준 것으로 사료된다.

본 연구에서는 고령의 4 기에 해당하는 비소세포성 폐암 환자 중 항암복합요법을 시행할 수 있는 환자를 대상으로 하다 보니 비교적 적은 환자수인 10 명을 대상으로 했고 고 령의 환자에게서 생물학적 나이를 고려하지 않았으며, 환 자의 삶의 질에 대한 분석이나 치료에 대한 만족도 등이 평가되지 않은 한계점을 가지고 있으며 사망한 환자의 사 망원인의 분석 역시 평가되지 않았다. 하지만, 실제적인 경
험적 연구로서 비소세포성 폐암에서 효과적인 항암제로 paclitaxel과 cisplatin의 저용량의 weekly 복합화학요법은 고 령에서의 진행된 비소세포성 폐암 환자의 1 차 치료법에 우 수한 반응을 보인 비교적 안전하게 사용할 수 있는 효과적 인 치료법이라 할 수 있으며 앞으로 많은 환자를 대상으로 한 연구 및 조사가 필요할 것이다.

\section{REFERENCES}

1. Report of the cause in Korea. Ministry of Health and Welfare 2004.

2. 2002 annual report of Korea Central Cancer Registry (published in 2004). Available form URL:http://www.ncc.re.kr

3. Jo HJ, Kim HK, Song SH, et al. Two years' result of lung cancer registry in St. Vincent's Hospital. Cancer Reser Treat 2002;34(Suppl 1):143(\#190).

4. Woo CM, Kim SY, Lee SA, et al. Paclitaxel for elderly patients with advanced NSCLC. The Korean Journal of Medicine 2006;70:183-189.

5. Socinski MA. Single-agent paclitaxel in the treatment of advanced non-small cell lung cancer. Oncologist 1999;4:408416.

6. Cardenal F, Lopez-Cabrerizo MP, Antón A, et al. Randomized phase III study of gemcitabine-cisplatin versus etoposidecisplatin in the treatment of locally advanced or metastatic non-small-cell lung cancer. J Clin Oncol 1999;17:12-18.

7. Bonomi P, Kim K, Fairclough D, et al. Comparison of survival and quality of life in advanced non-small-cell lung cancer patients treated with two dose levels of paclitaxel combined with cisplatin versus etoposide with cisplatin: results of an Eastern Cooperative Oncology Group trial. J Clin Oncol 2000; 18:623-631.

8. Giaccone G, Splinter TA, Debruyne C, et al. Randomized study of paclitaxel-cisplatin versus cisplatin-teniposide in patients with advanced non-small-cell lung cancer. J Clin Oncol 1998;16:2133-2141.

9. Arbuck SG. Paclitaxel: what schedule? What dose? J Clini Oncol 1994;12:233-236.

10. Rowinsky EK, Jiroutek M, Bonomi P, Johnson D, Baker SD. Paclitaxel steady-state plasma concentration as a determinant of disease outcome and toxicity in lung cancer patients treated with paclitaxel and cisplatin. Clin Cancer Res 1999;5:767774.

11. Klastersky J, Sculier JP, Ravez P, et al. A randomized study comparing a high and a standard dose of cispaltin in combination with etoposide in the treatment of advanced nonsmall-cell lung carcinoma. J Clin Oncol 1986;4:1780-1786.

12. Kim SW, Suh C, Lee SD, et al. Weekly low dose palclitaxel and cispaltin as first-line chemotherapy for advanced nonsmall cell lung cancer. Lung Cancer 2003;41:221-226.

13. The Elderly Lung Cancer Vinorelbine Italian Study Group. Effects of vinorelbine of quality of life and survival of elderly 
patients with advenced non-small-cell lung cancer. J Natl Cancer Inst 1999;91:66-72.

14. Gridelli C, Perrone F, Gallo C, et al. Chemotherapy for elderly patients with advanced non-small-cell lung cancer: the Multicenter Italian Lung Cancer in the Elderly Study (MILES) phase III randomized trial. J Natl Cancer Inst 2003;95:362372 .

15. Lilenbaum RC, Herndon JE 2nd, List MA, et al. Single-agent versus combination chemotherapy in advanced non-small-cell lung cancer: the cancer and leukemia group B (study 9730). J Clin Oncol 2005;23:190-196.

16. Gianni L, Kearns CM, Giani A, et al. Nonlinear pharmacokinetics and metabolism of paclitaxel and its pharmocokinetic/phamacodynamic relationships in humans. J Clin Oncol 1995;13:180-190.

17. Rowinsky E, Mackey M, Sn G. Meta-analysis of paclitaxel dose-response and dose-intensity in recurrent or refractory ovarian cancer. Proc Am Soc Clin Oncol 1996;15:284.

18. Yeung TK, Germond C, Chen X, Wang Z. The mode of action of taxol: apoptosis at low concentration and necrosis at high concentration. Biochem Biophys Res Commun 1999;263: 398-404.

19. Gergiadis MS, Schuler BS, Brown JE, et al. Paclitaxel by 96-hour continuous infusion in combination with cisplatin: a phase I trial in patients with advanced lung cancer. J Clin Oncol 1997; 15:735-743.

20. Kim R, Osaki A, Toge T. Pharmacokinetic and biochemical analysis in the treatment of weekly paclitaxel in relapsed breast cancer. Oncol Rel 2001;8:1171-1176.

21. Aisner J, Belani CP, Kearns C, et al. Feasibility and pharmacokinetics of paclitaxel, carboplatin, and concurrent radiotherapy for regionally advanced squamous cell carcinoma of the head and neck and for regionally advanced non- small-cell lung cancer. Semin Oncol 1995;22(5 Suppl. 12): 17-21.

22. Choy H, Rodriguez RC, Koester S, Hilsenbeck S, Von Hoff DD. Investigation of taxol as a potential radiation sensitizer. Cancer 1993;71:3374-3778.

23. Kim HK, Kim JS, Ryoo HN, et al. The efficacy and safety of padexol (paclitaxel) and cisplatin for treating advanced non-small cell lung cancer. Cancer Res Treat 2006;38:66-71. 